\title{
LITERATURE REVIEW: HUBUNGAN DYNAMIC BALANCE TERHADAP RESIKO TERJADINYA CEDERA PADA PEMAIN SEPAK BOLA
}

\author{
Nabilla Fitria Emily ${ }^{1}$, Heri Wibisono ${ }^{2 *}$ \\ ${ }^{1,2}$ Program Studi Fisioterapi Program Diploma Tiga, Fakultas Ilmu Kesehatan \\ Universitas Pembangunan Nasional Veteran Jakarta, Indonesia \\ *Email korespondesi : heri.wibisono@upnvj.ac.id
}

\begin{abstract}
ABSTRAK
Tujuan: Keseimbangan dinamis telah sedikit diselidiki atau di teliti disepak bola, terutama dalam hal pemainelit dan yang lebih penting, saat initidak diketahui apakah ada hubungan antara kemampuan keseimbangan statis dan dinamis. Penulisan karya ilmiah ini dilakukan dengan tujuan, untuk mengetahui hubungan keseimbangan terhadap resiko terjadinya cedera pada pemain sepak bola dan untuk memahami hubungan latihan FIFA 11+ pada keseimbangan dinamis pada pemain bola. Metode: Metode yang dilakukan pada penelitian ini dengan menggunakan metode literature review. Sumber data yang ada dalam penelitian ini adalah dengan menggunakan beberapa database seperti Google Scholar, PubMed, Science Direct. Dari hasil pencarian literature terdapat 3 artikel dan jurnal yang memenuhi kriteria inklusi. Sumber penilaian metodologi 3 arikel dengan Scimago Journal \& Country Rank (SJR) dan analisa jurnal menggunakan kesesuaian metode penelitian, topik yang digunakan, parmeter, dan hasil setiap artikel. Hasil: Setelah dilakukan telaah dengan literature sebanyak 3 artikel menunjukan bahwa dynamic balance dapat mengurangi resiko terjadinya cedera pada pemain sepak bola. Kesimpulan: Adanya hubungan dynamic balance pada terjadinya cedera terhadap pemain sepak bola yang signifikan.
\end{abstract}

Kata Kunci: Keseimbangan Dinamis, Cedera, Pemain Sepak Bola

\begin{abstract}
Objective: Dynamic balance has been little investigated or scrutinized in football, especially in the case of elite players and more importantly, it is currently unknown whether there is a relationship between static and dynamic balance abilities. The writing of this scientific work was carried out with the aim, to find out the relationship of balance to the risk of injury to soccer players and to understand FIFA 11+ training relationships on dynamic equilibrium for soccer players. Method: The method used in this research is using the literature review method. The data source in this research is to use several databases such as Google Scholar, PubMed, Science Direct. From the literature search results there are 3 articles and journals that meet the inclusion criteria. The source of the assessment methodology is 3 articles with Scimago Journal \& Country Rank (SJR) and journal analysis using the appropriateness of research methods, topics used, parameters, and the results of each article. Results: After a review of the literature with 3 articles shows that dynamic balance can reduce the risk of injury to soccer players. Conclusion: There is a dynamic balance relationship between the occurrence of injury to a significant soccer player.
\end{abstract}

Keywords: Dynamic Balance, Injury, Soccer Players 


\section{PENDAHULUAN}

Di Indonesia, olahraga sepak bola adalah olahraga yang digemari oleh masyarakat. Sepak bola Indonesia dimulai dari tahun 1914 saat Indonesia masih di kuasai oleh pemerintah Hindia Belnda. Asal muasal sepak bola modern di Indonesia dimulai dengan terbentuknya PSSI (Persatuan Sepakbola Seluruh Indonesia) pada tanggal 19 April 1930 di Yogyakarta yang diketuai oleh Soeratin Sosrosoegondo (Ferdiansah and Riyadi, 2019).

Sepak bola adalah olahraga yang membutuhkan banyak keterampilan teknis serta keseimbangan statis, semi-dinamis, dan dinamis. Sebagian besar keterampilan ini, seperti mengoper, menendang bola ke udara, menggiring bola atau menerima bola, dicapai dengan berdiri dengan satu kaki. Keseimbangan memiliki peran penting dalam kondisi yang keras, seperti mendorong lawan, perubahan pada cara mengelilingi bola, menghadapi pemain bola selama pertandingan (Dunsky, Barzilay and Fox, 2017).

Sepak bola dianggap sebagai olahraga paling ideal yang dapat meningkatkan keseimbangan dalam kondisi sehat, oleh karena itu latihan paling efektif dari semua metode latihan tradisional (Nikolaos et al., 2012).

Cedera yang sering terjadi pada pemain sepak bola adalah sprain, yang menyebab permainan sepak bola biasanya mengakibatkan cedera olahraga dari benturan atau luka secara langsung maupun latihan yang berulang-ulang dalam jangka waktu yang lama.

Risiko terjadinya cedera dibagi menjadi dua hal, yaitu faktor dalam keahlian atlet sendiri (intrinstik) dan faktor ekstrinsik. Cedera olahraga merupakan semua macam cedera yang muncul pada saat latihan maupun pada waktu permainan atau sesudah permainan. Cedera olahraga banyak jenisnya dan dapat digolongkankan berdasarkan proses, waktu cedera dan
Keseimbangan merupakan proses mempertahankan posisi pusat gravitasi tubuh secara vertikal di atas pangkal penopang dan mengandalkan kecepatan. Keseimbangan dinamis telah sedikit diselidiki disepak bola, terutama dalam hal pemain elit dan yang lebih penting, saat ini tidak diketahui apakah ada hubungan antara kemampuan keseimbangan statis dan dinamis (Pau et al., 2015).

Keseimbangan dinamis dapat dianggap sebagai kemampuan untuk melakukan tugas sembari mempertahankan atau mendapatkan kembali posisi stabil (Con, 2011). Federation International de Football Association atau disingkat FIFA merupakan kepanjangan yang didapatkan dari Bahasa prancis. FIFA sendiri lahir dikota paris untuk itu Bahasa prancis menjadi pilihan. FIFA $11+$ memiliki tiga bagian kelompok pemanasan yang berisikan dengan peregangan dan kontrol cedera. Bagian kedua adalah melakukan jenis 6 jenis latihan yang berfokus pada titik berat dan kekuatan kaki, keseimbangan, lompatan, kelincahan dengan masing-masing memiliki tiga tingkatan kesulitan. Bagian ketiga adalah latihan berlari dengan kecepatan menengah dan tinggi, yang dikombinasikan dengan gerakan menjejak dan menggunting.

FIFA $11+$ telah menunjukkan bagaimana program latihan sederhana diselesaikan sebagai bagian dari pemanasan dapat mengurangi insiden cedera di pemain sepak bola amatir. Secara umum, pengurangan besar dalam jumlah yang terluka pemain, berkisar antara $30 \%$ dan $70 \%$ telah diamati dalam menerapkan FIFA 11+ (Barengo et al., 2014).

Y Balance Test adalah contoh alat skrining yang digunakan secara klinis untuk menilai risiko cedera berdasarkan pola pergerakan abnormal, asimetri, dan keseimbangan dinamis (Chimera, Smith and Warren, 2015). YBT dapat bermanfaat untuk mengidentifikasi atlet yang rentan terhadap cedera.

Selama 10 tahun periode, semua pasien dengan cedera olahraga yang 
dirawat di klinik didokumentasikan yang dirancang khusus. Sejak implementasi kasus komputerisasi sejarah, 17.397pasien dengan 1.530 cedera telah dianalisis. 6.434 pasien $(37 \%)$ dengan 19.530 cedera $(39,8 \%)$ dengan sendi lutut (Majewski, Susanne and Klaus, 2010)

Berdasarkan penjelasan latar belakang diatas, peneliti sangat tertarik untuk meneliti tentang "Hubungan Dynamic Balance Terhadap Resiko Terjadinya Cedera Pada Pemain Sepak Bola”.

\section{METODE}

Penelitian ini bersifat deskriptif yaitu penjelasan dengan data yang telah didapat kemudian dijelaskan secara teratur dan terstruktur agar mampu di pahami dan dimengerti oleh pembaca. Pada penelitian ini memakai uji statistik ANOVA. Penelitian ini diubah menjadi penelitian literatur review. Cara yang digunakan ialah mengumpulkan sumber data atau yang berkaitan dengan masalah yang dibahas dalam penelitian tersebut. Literatur review ini bisa didukung oleh buku, jurnal, internet dan yang lainnya. Disini berfokus dengan menggunakan beberapa hasil pemikiran, teori hukum, serta pendapat yang digunakan untuk mengkaji dan menjawab pertanyaanpertanyaan dari rumusan masalah yang didapat.

\section{HASIL}

Penelitian ini mengenai keterikatan hubungan dynamic balance terhadap pemain bola yang dilakukan pada bulan April 2020 dengan melakukan pencarian jurnal melalui media elektronik ataupun internet dengan menggunakan rancangan penelitian literatur review.

Dari kelima literature yang telah dibahas menunjukan bahwa kelimanya menyatakn bahwa adanya hubungan antara dynamic balance terhadap resiko terjadinya cedera pada pemain sepak bola. Hal ini memperoleh hasil yang signifikan.
Penelitian ini dilakukan pada jurnal yang menjadi sample penelitian dalam sebuah penelitian yang telah di tentukan melalui kriteria inklusi dan eksklusi dari beberapa jurnal yang di dapatkan.

Penilaian kualitas metodologi artikel dengan menggunakan Scimago Journal Country Rank (SJR). SJR adalah salah satu pengukuran internasional yang berdasarkan dara dari scopus yang dikembangkan. Hasil dari penilaian kualitas metodologi artikel tersebut sebanyak 1 artikel dengan hasil rendah, 2 artikel dengan hasil kualitas sedang, dan 2 artikel dengan hasil kualitas tinggi. Dari studi yang digunakan untuk penelitian ini disampaikan bahwa adanya hubungan antara keseimbangan statis dengan resiko terjadinya cedera pada pemain sepak bola.

\section{PEMBAHASAN}

Pada penulisan ini penulis melakukan literature review mengenai jurnal yang sesuai dengan tema penelitian. Jurnal yang dipilih telah terpublikasi di internet secara nasional dan internasional dengan jangkauan minimal 5 tahun terakhir.

Dari gambaran di bab sebelumnya dapat disimpulkan bahwa tujuan utama dari masing-masing jurnal setelah direview adalah untuk mengetahui atau mengukur resiko terjadinya cedera pada pemain sepak bola terhadap keseimbangan dinamis.

Masing-masing jurnal mempunyai metode literature review yang hamper sama yaiitu cross sectional study dan ekperimental. Kelima jurnal tersebut juga memliki rata-rata sempel sebanyak 50, dimana sampel ini hanya untuk pemain sepak bola laki-laki, hal ini dapat disimpulkan bahwa rata-rata kelima jurnal ini didominasi oleh laki-laki. Kriteria usia yang digunakan dalam keseluruhan jurnal rata-rata adalah 17-30 tahun.

Pada jurnal pertama yang berjudul "Comparison of Static and Dynamic Balance At Different Levels of Sport Competition In Professional and Junior Elite Soccer Players" yang ditulis oleh (Jadczak et al., 2019) hasilnya adalah 
bahwa hasil terbaik adalah untuk menggunakan metode mata terbuka dan mata tertutup. Hasil yang lebih baik di peroleh untuk kaki yang tidak memiliki resiko terjadinya cedera. Kategori pro merupakan hasil sensitivitas keseimbangan untuk kaki dominan dan tidak dominan. Hal ini menunjukan bahwa kemampuan keseimbangan yang baik dalam kondisi statis dan dinamis untuk kedua kaki yang penting untuk kesuksesan olahraga. Studi sebelumnya menjelaskan bahwa parktek jangka Panjang dalam aktifitas olahraga dengan keterampilan memerlukan keseimbangan tingkat tinggi. Pada penelitian ini juga menemukan bahwa latihan sepak bola jangka panjang dapat memberikan efek yang lebih baik terhadap pemain. Hasil survey ini menunjukan bahwa postural control membaik dengan adanya tinggak level olahraga dan menunjukan kemampuan yang lebih dalam sepak bola. Keseimbangan yang mendasari gerakan koordinasi dan korelasi yang signifikan anatara keseimbangan dapat meningkatkan kompetensi yang diamat dalam penelitian ini.

Pada jurnal kedua yang berjudul "Comparing The Static and Dynamic Balance and Their Relationship with the Anthropometrical Charactaeristics in the Athletes of Selected Sports" yang ditulis oleh (Tabrizi, Abbasi and Sarvestani, 2013) hasilnya adalah menunjukan adanya korelasi atau hubungan yang bermakna antara keseimbanagan statis. Ini mengartikan bahwa semakin tinggi seseorang maka semakin rendah keseimbangan statisnya. Hasil penelitian ini sesuai dengan Chaiari et al yang menjunjukan bahwa ketinggian memiliki hubungan yang signifikan dengan pusat Gerakan massa dikedua arah yaitu antara anterior dan posterior. Tetapi hasil ini tidak sesuai dengan hasil dari Berger et al, mereka menyelidiki adanya hubungan ketinggian dengan Gerakan pengatur ayunan tubuh untuk menjaga keseimbangan dengan basis dukungan yang terbatas.
Pada jurnal ke tiga yang berjudul "Relationship Between The Y Balance Test Scores And Soft Tissue Injury Incidence In A Soccer Team" yang ditulis oleh (Gonell, Romero and Soler, 2015) yang hasilnya adalah Tidak ada yang signifikan meskipun ada skor di mana beberapa jenis hubungan mungkin ada. Meskipun basket dapat dibandingkan dengan sepak bola dalam beberapa aspek, ada beberapa perbedaan berdasarkan kinerja yang mungkin menjelaskan perbedaan dalam hasil studi. Pada jurnal ke empat yang berjudul "Immediate effect of ankle balance taping on dynamic and static balance of soccer players with acute ankle sprain" yang ditulis oleh (Shin and Kim, 2017) yang hasilnya adalah Limits of stability (LOS) ukuran keseimbangan dinamis meningkat secara signifikan dibandingan dengan placebo taping dan tidak menggunakan taping. Penerapan Ankle Balance Taping yang menggunakan kinesiology tape secara instan meningkatkan kemampuan keseimbangan statis dan dinamis pemain sepak bola dengan ankle sprain.

Pada jurnal yang terakhir atau ke lima yang berjudul "Preseason Dynamic Balance Performance in Healthy Elite Male Soccer Players" yang ditulis oleh (Onofrei et al., 2019) yang hasilnya adalah Hasil yang sama ditemukan pada peneliti lain. Kinerja keseimbangan dinamis dinilai hanya dalam satu evaluasi fisik dan tidak ada tindak lanjut saat ini untuk mencatat kemungkinan cedera ekstremitas bawah yang tidak berhubungan. komposit yang lebih tinggi untuk tungkai dominan. Asimetri dalam arah posteromedial dan posterolateral secara signifikan lebih tinggi daripada di arah anterior.

Berdasarkan penelitian ini dengan menggunakan lima literature yang telah dirangkum dan dianalisa. Rata-rata keseimbangan merupakan salah satu hal yang diperlukan dalam mengurangi resiko terjadinya cedera pada pemain sepak bola. Kemampuan keseimbangan pada dasarnya bukanlah merupakan suatu kondisi yang 
perlu diperhatikan dalam terjadinya cedera, tetapi ketika cedera terjadi salah satu faktornya merupakan keseimbangan dan kemudian memberikan efek pada atlet sepak bola tersebut

Menurut beberpa penelitian, keseimbangan merupakan kemampuan yang paling utama dalam mempertahankan gravitasi pda bagian tumpu seseorang, terutama pada posisi berdiri. Karena keseimbangan yang tidak cukup baik telah dikaitkan dengan peningkatan resiko cedera pada atlet, maka dari keseimbangan dinamis merupakan salah satu hal yang penting untuk mengurangi resiko terjadinya cedera kepada para pemain sepak bola.

Dari referensi yang sudah didapatkan adalah bahwa adanya kaitan keseimbangan dengan terhadap resiko terjadinya cedera pada pemain sepak bola dan adanya hubungan yang signifikan. Para pemain sepak bola mempunyai aktivitas yang cukup berat dalam melakukan latihan untuk mencapai kejuaraan olahraga. kesimbangan merupakan kemampuan untuk mempertahankan pusat kekuatan pada bidang tumpu pokok ketika saat posisi sigap (Afafah, 2018).

Adanya hubungan yang memperlihatkan antara keseimbangan keseimbangan dinamis dan antropometri semacam tinggi badan, berat badan, perimeter panggul, Panjang kaki dan BMI (Tabrizi, Abbasi and Sarvestani, 2013). Hubungan keseimbangan dengan resiko terjadinya cedera adalah adanya hubungan dengan sistem saraf agar tetap bisa menjaga keseimbangan tubuhnya dan mengurangi resiko terjadinya cedera pada pemain sepak bola.

\section{KESIMPULAN}

Berdasarkan dari rumusan masalah yaitu "Apakah Terdapat Hubungan Dynamic Balance Terhadap Resiko Terjadinya Cedera Pada Pemain Sepak Bola?" dari hasil analisa dan pembahasan yang di simpulkan bahwa "adanya hubungan dynamic balance pada terjadinya cedera terhadap pemain sepak bola yang signifikan" yang didasarkan dari pembahasan-pembahasan yang di dapat dari beberapa jurnal yang telah di analisa.

\section{DAFTAR PUSTAKA}

Afafah, muh nur fahri 2018 'Analisis Keseimbangan Statis Dan Keseimbangan Dinamis WanitaPaguyuban Olahraga Lansia Perumahan Pongangan Indah Gresik', Jurnal Kesehatan Olahraga, 6(2), p. 295.

Barengo, N. C. et al. 2014 'The impact of the fifa $11+$ training program on injury prevention in football players: A systematic review', International Journal of Environmental Research and Public Health, 11(11), pp. 1198612000. doi: 10.3390/ijerph111111986.

Chimera, N. J., Smith, C. A. and Warren, M. 2015 'Injury history, sex, and performance on the functional movement screen and Y balance test', Journal of Athletic Training, 50(5), pp. 475-485. doi: 10.4085/1062-605049.6.02.

Con, H. 2011 '14 Balance ability and athletic performance', Sport Medicine, 41(3), p. 222. Dunsky, A., Barzilay, I. and Fox, O. 2017 'Effect of a specialized injury prevention program on static balance, dynamic balance and kicking accuracy of young soccer players', World Journal of Orthopaedics, 8(4), pp. 317-321. doi: 10.5312/wjo.v8.i4.317.

Ferdiansah, R. and Riyadi, S. 2019 'Universitas Muhammadiyah Purworejo Implementasi Fungsi Manajemen Pembinaan Sepakbola Usia The 9 Th University Research Colloqium $2019 \quad$ Universitas Muhammadiyah Purworejo'. 
Gonell, A. C., Romero, J. A. P. and Soler, L. M. 2015 'Relationship Between the Y Balance Test Scores and Soft Tissue Injury Incidence in a Soccer Team.', International journal of sports physical therapy, 10(7), pp. 955-66. Available

at: http://www.ncbi.nlm.nih.gov/pubmed/ 26673848\%0Ahttp://www.pubmedcen tral.nih.gov/articlerender.fcgi?artid=P MC4675196.

Jadczak, Ł. et al. 2019 'Comparison of Static and Dynamic Balance at Different Levels of Sport Competition in Professional and Junior Elite Soccer Players', Journal of strength and conditioning research, 33(12), pp. 3384-3391. doi: 10.1519/JSC.0000000000002476.

Nikolaos, K. et al. 2012 'The effect of a balance and proprioception training program on amateur basketball players' passing skills', Journal of Physical Education and Sport, 12(3), pp. 316323. doi: 10.7752/jpes.2012.03047.

Onofrei, R. R. et al. 2019 'Preseason Dynamic Balance Performance in Healthy Elite Male Soccer Players', American Journal of Men's Health, 13(1). doi: $10.1177 / 1557988319831920$.

Pau, M. et al. 2015 'Relationship between static and dynamic balance abilities in Italian professional and youth league soccer players', Physical Therapy in Sport. Elsevier Ltd, 16(3), pp. 236241. doi: 10.1016/j.ptsp.2014.12.003.

Senfiks, P., Nasional, S. and Ilmu, F. 2019 'Copyright (C2019 FIKS, Universitas PGRI Madiun. ISSN: 2657-0211 (Online) 1', 1(1), pp. 1-19.

Shin, Y. J. and Kim, M. K. 2017 'Immediate effect of ankle balance taping on dynamic and static balance of soccer players with acute ankle sprain', Journal of Physical Therapy Science, 29(4), pp. 622-624. doi: $10.1589 /$ jpts.29.622.

Tabrizi, H. B., Abbasi, A. and Sarvestani, H. J. 2013 'Comparing the static and dynamic balances and their relationship with the anthropometrical characteristics in the athletes of selected sports', Middle East Journal of Scientific Research, 15(2), pp. 216221. doi:10.5829/idosi.mejsr.2013.15.2.742 6. 